\title{
PRAKTEK GHARAR PADA ENDORSEMENT PRODUK DI MEDIA SOSIAL INSTAGRAM
}

\author{
Angga Syahputra dan Yoesrizal M. Yoesoef \\ Institut Agama Islam Negeri Lhokseumawe \\ Email: anggasyahputra@iainlhokseumawe.ac.id dan yoesrizal@iainlhokseumawe.ac.id
}

\begin{abstract}
Sales of products using the endorsement method on Instagram social media are a trend. This method is considered effective and efficient by producers in marketing their products. In marketing products on Instagram social media, producers usually hook Instagram celebrities who have a large number of followers. With a large number of followers, in fact, endorsers often practice gharar in marketing products. Gharar practices carried out by endorsers can be in the form of information conveyed as well as practiced practices. This study uses a qualitative type with empirical juridical methods by comparing the laws that should exist with the reality that occurs in society. The results of the study explained that in order to avoid the practice of gharar in product endorsement, endorsers must understand the terms and conditions of trading, be honest and uphold ethics in muamalah.
\end{abstract}

Keywords: Gharar, Endorsement, and Instagram.

\begin{abstract}
Abstrak
Penjualan produk dengan metode endorsement pada media sosial instagram sedang trend dilakukan. Metode ini dinilai efektif dan efesien oleh produsen dalam memasarkan produknya. Dalam memasarkan produk di media sosial instagram, biasanya produsen menggaet selebritis instagram yang memiliki jumlah folloowers yang banyak. Bermodal followers yang banyak, pada kenyataannya, endorser kerap melakukan praktek gharar dalam memasarkan produk. Praktek gharar yang dilakukan endorser dapat berupa informasi yang disampaikan maupun praktek yang dilakukan. Penelitian ini menggunakan jenis kualitatif dengan metode yuridis empiris dengan mengkomparasikan antara hukum yang seharusnya ada dengan kenyataan yang terjadi di masyarakat. Hasil penelitian memaparkan guna menghindari praktek gharar dalam endorsement produk, endorser harus memahami rukun dan syarat dalam jual-beli, bersikap jujur serta menjunjung tinggi etika dalam muamalah.
\end{abstract}

Kata Kunci: Gharar, Endorsement, dan Instagram. 


\section{PENDAHULUAN}

Memasuki era digitalisasi 4.0., metode penjualan terhadap produk mengalami perubahan besar-besaran. Jika dulu produk dipasarkan dengan menggunakan media elektronik seperti televisi; radio, media cetak seperti koran; majalah atau menggunakan cara konvensional dengan memasarkan dari rumah ke rumah, maka saat ini cara-cara tersebut mulai ditinggalkan, kecuali media elektronik. Saat ini produsen lebih memilih memasarkan produknya menggunakan media sosial, seperti instagram.

Islam merupakan agama yang paripurna, tidak hanya mengatur masalah ibadah secara vertikal kepada Allah Swt. namun juga mengatur masalah ibadah secara horizontal kepada sesama manusia. Ada banyak bentuk ibadah secara horizontal dalam Islam, termasuk berdagang dan memberikan informasi yang benar kepada orang lain.

Setiap Muslim dituntut untuk memberikan pencitraan positif terhadap dirinya, orang lain dan lingkungan. Setiap jiwa bertanggungjawab terhadap dirinya dan lingkungan sekitarnya, untuk itu dalam transaksi ekonomi, Islam menolak adanya unsur penipuan, ketidakjelasan, ataupun cara-cara lain yang dianggap bathil (Hosen, 2009).

Seorang Muslim harus bersikap jujur. Kejujuran dan kebenaran merupakan nilai yang penting dalam suatu transaksi maupun kerjasama. Berkaitan dengan ini, bentuk penipuan, sikap eksploitasi, membuat pernyataan palsu adalah dilarang sebab dari segi sosial dan hukum ia akan dimintai pertanggungjawaban atas perbuatan tersebut (Muttaqin, Transaksi E-Commerce Dalam Tinjauan Hukum Jual Beli Islam , 2010).

Gharar secara bahasa dapat diartikan bahaya, sedangkan makna lainnya berasal dari kata taghrir yang bermakna menjerumuskan diri ke dalam gharar (Manzur, 1993). Secara khusus gharar dapat diartikan sebagai pihak yang merasa ditipu karena telah mengkonsumsi sesuatu yang tidak halal atau terjerumus ke dalam suatu kesalahan yang disangka benar (Rahman, 2018).

Imam Nawawi mengatakan bahwa persoalan transaksi gharar banyak terjadi di masyarakat namun sedikit sekali orang yang mengetahuinya. Begitupun pada transaksinya tidak banyak orang yang mengetahui batasan-batasan gharar, kecuali setelah memahami apa maksud gharar dan mengetahui seluk-beluk kasus yang terkait. Gharar merupakan satu dari tiga hal larangan dalam transaksi yang disebutkan Rasulullah Saw. Apabila terdapat gharar dalam sebuah transaksi, maka hal tersebut haram dan menjadi batal (Uddin, 2015).

Saat ini dalam melakukan penjualan produk, pihak produsen biasanya menggaet selebgram dengan kesepakatan pembayaran pada nominal tertentu untuk memasarkan produk yang akan dijual. Selebgram merupakan singkatan dari selebritis instagram, sebuah istilah yang disematkan pada pengguna instagram yang memiliki banyak followers. Media sosial instagram saat ini merupakan media sosial yang sedang booming, aplikasi berbagi foto, video baik melalui beranda atau feed ini digandrungi berbagai macam kalangan, khususnya anak muda karena berbagai macam kelebihannya. Selebgram biasanya memasarkan produk dalam bentuk barang atau jasa pada akun instagram milik pribadi baik pada feed instagram maupun pada beranda. Sayangnya, produk yang di-review kebanyakan kualitas maupun efek penggunaannya tidak sesuai dengan yang disampaikan, seperti penjualan krim pemutih, penghilang jerawat, barang elektronik, dan lain sebagainya.

Kasusnya dapat diambil misalnya pada penjualan krim kecantikan, biasanya selebgram akan memberikan review bahwa produk tersebutl yang membuatnya cantik/tampan, putih atau terbebas dari jerawat. Pada kenyataannya, selebgram tersebut cantik/tampan, putih dan tidak berjerawat bukan dikarenakan krim tersebut, melainkan produk atau treatment lainnya. Ironisnya lagi produk yang ditawarkan tidak memiliki sertifikat halal maupun izin dari BPOM. Untuk itu penulis akan melakukan 
kajian terhadap kegiatan endorsement tersebut dalam sudut pandang Islam, sehingga menjadi jelas terhadap aktifitas yang dilakukan tersebut.

\section{LITERATURE REVIEW}

Hamid dalam penelitiannya mengungkapkan banyak pelaku endorsement di media sosial tidak mengetahui jual-beli yang mereka lakukan apakah sesuai dengan hukum Islam atau sebaliknya. Produsen dan pihak endorser harus memastikan produk yang dijual tidak mengandung unsur yang diharamkan, tidak terdapat riba, tidak merugikan pihak konsumen, tidak ada unsur penipuan dan memastikan keamanan konsumen sehingga transaksi tersebut benarbenar halal (Hamid, 2016).

Aksamawanti

sendiri mengungkapkan bahwa transaksi dalam kegiatan bisnis dan ekonomi, antara kedua belah pihak tidak hanya didasarkan kondisi saling membutuhkan, melainkan sebuah manifesati tolong-menolong antar manusia, untuk itu tidak dibenarkan adanya unsur kecurangan yang mengakibatkan para pihak saling rugi, karena akan menyebabkan jatuhnya hukum haram. Bentuk gharar dapat ditemukan dalam subjek, objek dan sighat. Suatu akad dapat rusak dan keabsahannya berpengaruh, jika unsur-unsur gharar terpenuhi yakni termasuk akad mu'âwadhah (bisnis), termasuk gharar banyak (berat), gharar yang terjadi pada pokok objek akad (bukan pelengkapnya) dan tidak ada kebutuhan syar'i terhadap akad (Aksamawanti, 2019).

Muttaqin menjelaskan pelaku usaha dalam bisnis e-commerce harus bersikap jujur. Berbagai bentuk penipuan, eksploitasi, membuat pernyataan palsu adalah dilarang. Selain itu objek yang ditransaksikan harus dipastikan halal, memperjelas objek yang ditransaksikan agar tidak terdapat gharar yang membuat konsumen rugi (Muttaqin, 2010).

\section{METODE PENELITIAN}

Jenis penelitian ini adalah kualitatif dengan menggunakan pendekatan yuridis empiris.
Penelitian yuridis merupakan penelitian yang melihat hukum sebagai norma atau aturan. Sumber hukum yang digunakan dalam penelitian ini adalah Alquran, Hadis, serta ijma'. Penelitian yuridis adalah hukum sebagai kenyataan sosial ataupun kultural, dimana dalam penelitian ini, peneliti melakukan kajian apa yang terjadi di masyarakat dengan penggunaan media sosial instagram dan aspek hukum dalam Islam tentang aktivitas tersebut.

Penelitian ini disempurnakan dengan kajian literatur yang sudah ada, seperti dari buku serta penelitian-penelitian terdahulu yang mengkaji tentang gharar, penggunaan media sosial maupun muamalah.

\section{METODE PENELITIAN}

Jenis penelitian ini adalah kualitatif dengan menggunakan pendekatan yuridis empiris. Penelitian yuridis merupakan penelitian yang melihat hukum sebagai norma atau aturan. Sumber hukum yang digunakan dalam penelitian ini adalah Alquran, Hadis, serta ijma'. Penelitian yuridis adalah hukum sebagai kenyataan sosial ataupun kultural, dimana dalam penelitian ini, peneliti melakukan kajian apa yang terjadi di masyarakat dengan penggunaan media sosial instagram dan aspek hukum dalam Islam tentang aktivitas tersebut.

Penelitian ini disempurnakan dengan kajian literatur yang sudah ada, seperti dari buku serta penelitian-penelitian terdahulu yang mengkaji tentang gharar, penggunaan media sosial maupun muamalah.

\section{KONSEP DASAR}

\section{Gharar dalam Pandangan Islam}

Mencari tahu tentang gharar dalam transaksi muamalah adalah sebuah kewajiban, karena mencari pengetahuan adalah wajib bagi setiap Muslim (Saiti \& Abdullah, 2016). Gharar dalam bahasa Arab berarti al-khathr (pertaruhan), majhul al-aqibah (tidak jelas hasilnya), al-jahalah (ketidakjelasan). Secara makna lain, gharar dapat berarti suatu penampilan yang menimbulkan kerusakan, atau sesuatu yang tampaknya menyenangkan, namun dalam realitasnya justru 
memunculkan kebencian (al-Zuhayli, 2004). Gharar merupakan bentuk tipuan, keraguan, atau kegiatan yang menyebabkan kerugian pada orang lain. Gharar dari segi ilmu fikih dapat dikatakan sebagai suatu penipuan, ketidakjelasan, tidak mengetahui barang yang dijual, tidak dapat diserahkan serta adanya unsur ketidakrelaan. Abdurrahman As-Sa'di dalam kitab Fiqh al-Bay wa AsySyira, termasuk jual-beli gharar bila seorang penjual menipu saudara Muslimnya dalam melakukan penjualan barang/jasa (Junaedi, 2016). Penyebab gharar dilarang adalah karena hubungannya dengan memakan harta orang lain dengan cara tidak benar, bukan semata-mata adanya unsur resiko, ketidakpastian ataupun istilah lain game of chance, karena hal ini akan merugikan pihak lain (al-Saati, 2003).

Rasulullah Saw. dengan tegas melarang praktek gharar, sebagaimana Hadis yang diriwayatkan Imam Bukhari dan Muslim, "Rasulullah Saw. melarang jual-beli yang mengandung gharar (ketidakpastian)" (al-Qusyairi, t.t.). Esensi dari pelarangan gharar ini adalah manat al-hukm, mencegah terjadinya perselisihan dan hal ini tidak dapat ditoleransi (Al-Saati, 2003).

\section{Endorsement Dalam Pandangan Islam}

Dalam Islam melakukan muamalah dengan syarat halal adalah mutlak. Halal tidak hanya dari dzatnya, tetapi juga menyangkut keseluruhan, baik cara mempromosikannya, cara bermuamalahnya, maupun cara mendapatkannya. Mengambil keuntungan dengan jalan atau cara yang tidak benar dilarang dalam Islam, hal ini sesuai dengan firman Allah Swt. dalam Alquran, "Dan janganlah kamu memakan harta sesama kamu dengan cara yang bathil..." (QS. AlBaqarah: 188). Yusuf al-Qardhawi menjelaskan bahwa yang dimaksud memakan adalah menerima, mengambil, dan menguasai (Al-Qardhawi, 2014). Larangan

${ }^{1}$ Fatwa MUI No. 24 Tahun 2017 Tentang Hukum dan Pedoman Bermuamalah Melalui Media Sosial memakan ini ditegaskan baik dalam cara memperolehnya maupun cara memanfaatkannya (Taufiq, 2018). Kata batil sendiri memiliki kata dasar bathil yang bermakna fasid atau sia-sia, tidak berguna, bohong. Al-Bathil sendiri berarti yang salah, palsu, tidak berharga, sia-sia (Munawwir, 1997).

Endorsement merupakan aktifitas yang belakangan marak dilakukan banyak orang, terkhusus selebgram. Endorsement merupakan kegiatan memasarkan barang atau jasa terutama pada media sosial instagram. Istilah lain dari aktifitas ini adalah mempromosikan barang atau jasa menggunakan media sosial. Instagram atau media sosial lainnya, pada dasarnya diciptakan bukanlah tempat untuk berbisnis, hanya saja trend pengguna yang semakin meningkat, membuat produsen melirik hal ini untuk dijadikan media dalam berbisnis. Endorsement saat ini merupakan kegiatan yang cepat dan tepat. Selain murah, endorsement dipandang efektif karena tertuju langsung kepada calon customer. Pelaku dari endorsement biasanya disebut dengan istilah endorser.

American Marketing Association menjelaskan aktifitas endorsement adalah "any paid form of nonpersonal communication about an organization, product, service, or idea by an identified sponsor" (Morissan, 2010). Berdasarkan keterangan tersebut, endorsement dapat dikategorikan sebagai sebuah periklanan.

Sebagaimana kaidah dasar dalam ushul fiqh tentang muamalah bahwa pada dasarnya boleh dilakukan, kecuali ada dalil yang mengharamkannya (Mardani, 2012). Muamalah adalah proses interaksi antar individu atau kelompok yang terkait dengan hablun minannas meliputi proses pembuatan (produksi), penyebaran (distribusi), akses (konsumsi) dan penggunaan informasi dan konsumsi. ${ }^{1}$ Jika mengikut pada kaidah dasar ushul fiqh, maka kegiatan endorse produk 
juga hukum asalnya boleh, asalkan tidak mengandung unsur-unsur yang dilarang syariat Islam. Endorsement produk dapat menjadi haram jika produk yang dijual terdapat unsur gharar, penipuan, tidak memberikan manfaat yang baik, mengandung mudharat, dan unsur manipulasi (Redaksi).

Strategi endorsement adalah strategi komunikasi pemasaran dengan menggunakan tokoh terkenal seperti artis, fashion blogger, fashion stylish dan lain-lain sebagai alat pendukung dan penunjang agar masyarakat tertarik dengan produk yang ditawarkan di media sosial yang digunakan (Utami, 2014). Secara implisit Imam alGhazali dalam kitab Ihya' Ulum al-Din menjelaskan dan menekankan dalam aktifitas endorsement ini untuk mengikuti etika muamalah secara Islami, diantaranya (AlGhazali, 2005): 1) Aktifitas endorse harus berlandaskan unsur keadilan, kebaikan, kebajikan dan tidak adanya kezholiman; 2) Adanya transparansi antara endorser dan konsumen, sehingga tidak terjadi kecurangan; 3) Aktifitas endorse tidak hanya untuk mengejar keuntungan dunia semata, karena keuntungan yang sebenarnya adalah akhirat; 4) Menjauhkan dari transaksitransaksi yang syubhat.

Dari Abdullah bin Mas'ud Ra., ia berkata: "Rasulullah Saw. bersabda: "Wajib atas kalian berlaku jujur, karena sesungguhnya jujur itu menunjukkan (pelakunya) kepada kebaikan, dan kebaikan itu menunjukkan kepada Surga (HR. Muslim). Sesuai dengan Fatwa MUI No. 24 tahun 2017 Tentang Hukum dan Pedoman Bermuamalah Melalui Media Sosial, bahwa dalam melakukan aktifitas muamalah melalui media sosial, konten/informasi yang di-share harus benar, baik dari sisi isi, sumber, waktu dan tempat, latar belakang serta konteks informasi disampaikan. Dalam artian lain fatwa ini secara eksplisit menerangkan bahwa tidak boleh ada unsur gharar dalam menjualkan barang secara online. Dengan kata lain produk yang dijual harus jelas, baik dari segi fisiknya, kegunaannya, serta informasi yang disampaikan (tidak ada unsur penipuan).

Kaplan dan Haenlin mendefinisikan media sosial adalah suatu grup aplikasi berbasis internet yang menggunakan ideologi dan teknologi web 2.0, dimana pengguna dapat membuat atau bertukar informasi pada aplikasi tersebut (Kaplan \& Haenlein, 2010). Dalam memasarkan produk di media sosial memiliki beberapa dimensi, yaitu online communities, interaction, sharing of content, accessibility, credibility. Media sosial memiliki beberapa perbadaan dengan media pemasaran lainnya, yaitu always on dan everywhere (Powers, Advincula, \& Austin M, 2012). Pengguna media sosial dapat menggakses kapan saja dan dimana saja, karena selain diakses melalui komputer dapat diakses melalui mobile/smarth phone. Hal inilah yang memberikan peluang bagi para pemasar untuk dapat melakukan komunikasi pemasaran kapan saja dan dimana saja bagi calon customer.

Perkembangan pengguna instagram memuncak luar biasa. Aplikasi yang bermula dari aplikasi foto sederhana kini mengalami banyak perubahan dan menjadi sebuah platform yang memungkinkan pengguna membangun identitas visual bisnis mereka (Untari \& Fajariana, 2018). Instagram dapat menampilkan foto-foto secara instan dalam tampilannya, ini sebab aplikasi ini jika dipisah menjadi dua kata, dari kata instant dan gram. Untuk kata gram sendiri berasal dari kata telegram, dimana cara kerja telegram adalah mengirimkan informasi kepada orang lain dengan cepat. Begitu pula halnya dengan instagram yang dapat mengunggah foto dengan menggunakan jaringan internet, sehingga informasi yang disampaikan dapat diterima dengan cepat.

Per November 2019, NapoleonCat perusahaan analis Social Media Marketing yang berbasis di Warsawa, Polandia menyebutkan 22,6\% dari total penduduk Indonesia aktif menggunakan instagram. Jumlah ini menembus angka 61.610.000 penduduk, jumlah yang tidak sedikit dan tercatat sebagai pengguna aktif terbesar ke empat di dunia (Pertiwi, 2019). 


\section{PEMBAHASAN DAN DISKUSI}

\section{Praktek Gharar di Media Sosial Instagram}

Saat ini produk yang unik, produk yang berbeda, dibungkus dengan manipulasi dianggap menjadi sebuah kekuatan pasar dalam menggaet calon konsumen (Mowla, 2019). Umumnya praktek endorsement produk di media sosial instagram dapat jatuh hukumnya menjadi haram dikarenakan tiga sebab: informasi yang asimetris (Black, 1997), produk yang tidak spesifik, serta adanya ketidakpastian (Bishop, 2004), baik dari segi produk yang dijual maupun dari penjual itu sendiri.

Konsep gharar dapat dibagi menjadi dua kelompok, 1) Unsur resiko yang mengandung keraguan, probabilitas dan ketidakpastian secara dominan. 2) Unsur meragukan yang dikaitkan dengan penipuan atau kejahatan oleh salah satu pihak terhadap pihak lainnya (Warde, 2001). Alquran dengan tegas telah melarang semua transaksi bisnis yang mengandung unsur kecurangan dalam segala bentuk terhadap pihak lain, hal itu mungkin dalam segala bentuk penipuan atau kejahatan, atau memperoleh keuntungan dengan tidak semestinya atau resiko yang menuju ketidakpastian di dalam suatu bisnis atau sejenisnya sebagaimana terdapat dalam QS. Al-An'am: 152.

Begitu juga halnya dengan hukum gharar, dimana aktivitas ini merupakan situasi dimana terjadi uncomplete information karena adanya ketidakpastian kedua belah pihak yang bertransaksi, dan bahkan mengubah sesuatu yang seharusnya bersifat pasti menjadi tidak pasti. Hal semacam ini dilarang dalam bertransaksi (Nur, 2015). Sebagaimana diungkapkan oleh Ibnu Taimiyah bahwa gharar adalah sesuatu yang majhul (tidak diketahui) akibatnya (Taimiyah, 2002), sedangkan pandangan Sayyid Sabiq gharar merupakan penipuan yang mana dengannya diperkirakan mengakibatkan tidak ada kerelaan jika diteliti (Sabiq, 1994). Dalam ilmu fiqih sendiri gharar adalah ketidaktahuan terhadap akibat suatu perkara, kejadian/peristiwa dalam transaksi jual-beli, atau ketidakjelasan antara baik dan buruknya.
Suatu akad dikatakan batil apabila akad itu tidak memenuhi salah satu rukunnya atau ada larangan langsung dari syara'. Misalnya, objek jual-beli tidak jelas, terdapat unsur penipuan, atau salah satu pihak yang berakad tidak cakap hukum. Adapun akad fasid merupakan suatu akad yang pada dasarnya tidak disyariatkan, akan tetapi sifat yang diakadkan itu tidak jelas (Lidinillah \& Mawardi, 2015).

\section{Penyebab Endorsement Menjadi Gharar}

Dari uraian pandangan hukum dan literatur yang ada, praktek endorsement produk pada media sosial instagram menjadi gharar jika terjadi hal-hal berikut: Pertama, ketidakjelasan dalam jenis objek akad. Mengetahui jenis objek yang diperjualbelikan merupakan syarat sah dari jual-beli. Maka, jika objek yang diperjual-belikan pada instagram tidak diketahui, hukumnya tidak sah (Haroun, 2000).

Kedua, ketidakjelasan dalam macam objek akad. Akad seperti ini tidak sah karena mengandung unsur ketidakjelasan dalam objeknya (Syahatah \& Adh-Dhahir, 2005). Contohnya seorang penjual berkata, "saya jual kepada anda cream pencerah wajah dengan harga sekian" tanpa menjelaskan cream apa, sifatnya bagaimana, kegunaan dan unsur pelengkap lainnya.

Ketiga, ketidakjelasan dalam sifat dan karakteristik objek transaksi. Terdapat beberapa pendapat imam mazhab dalam hal ini, diantara perbedaan itu adalah; Mazhab Hanafiyah melihat, bahwa jika obyek transaksinya terlihat dalam transaksi, baik itu komoditi ataupun uang, maka tidak perlu untuk mengetahui sifat dan karakternya. Namun, jika obyek transaksinya tidak terlihat oleh penjual dan pembeli, maka para ulama fiqh mazhab Hanafiyah berselisih pendapat. Sebagian berpendapat perlu penjelasan sifat dan karakter obyek akad, dan sebagian tidak. Pendapat yang tidak mensyaratkan menyebutkan bahwa ketidaktahuan sifat tidak menyebabkan perselisihan, disamping itu pembeli juga mempunyai hak khiyar ru'yah. Silang pendapat di atas adalah yang berkaitan dengan komoditi bukan harga, 
adapun tentang harga (tsaman) semua ulama sepakat untuk disebutkan sifat dan karakternya (Rusyd, 1981). Mazhab Maliki mensyaratkan penyebutan sifat dan karakter baik terhadap komoditi maupun harga (tsaman). Mazhab Maliki berpendapat bahwa tidak adanya kejelasan dalam sifat dan karakter komoditi dan harga adalah merupakan gharar yang dilarang dalam akad. Begitu juga ulama mazhab Syafi'i mensyaratkan penyebutan sifat dan karakter komoditi dan mengatakan bahwa jual-beli yang tidak jelas sifat dan karakter komoditinya hukumnya tidak sah kecuali jika pembeli diberi hak untuk melakukan khiyar ru'yah. Mazhab Hambali juga tidak membolehkan jual-beli yang obyek transaksinya tidak jelas sifat dan karakternya (Syahatah \& Adh-Dhahir, 2005).

Keempat, ketidakjelasan pada ukuran objek transaksi (Syahatah \& Adh-Dhahir, 2005). Dijelaskan pula tidak sah jual-beli sesuatu yang kadarnya tidak diketahui, baik kadar dari komoditi yang diperdagangkan, maupun kadar dari harganya. Jika unsur ini tidak terpenuhi, maka sudah terjadi gharar sebagaimana pendapat Imam Malik dan Imam Syafi'i.

Kelima, ketidaktahuan dzat dalam objek yang diperjual-belikan. Seorang Muslim diwajibkan untuk mengkonsumsi/ menggunakan barang yang halal dzatnya, sebagaimana perintah Alquran dan Hadis Rasulullah Saw. Ketidaktahuan dalam dzat objek transaksi adalah bentuk dari gharar yang terlarang, hal ini juga dapat menimbulkan perselisihan. Untuk itu penting bagi endorser memberikan informasi yang jelas kepada calon konsumen terhadap produk yang dipromosikan (Rusyd, 1981). Endorser juga harus menginformasikan bahwa produk yang dijual adalah produk yang halal dan baik, serta memiliki izin dari BPOM.

Keenam, ketidakmampuan dalam penyerahan komoditi. Anwar (2007:191) menjelaskan bahwa kemampuan menyerahkan obyek transaksi adalah syarat sahnya dalam jual-beli. Maka jika obyek transaksi tidak dapat diserahkan, secara otomatis jual-belinya tidak sah karena terdapat unsur gharar (tidak jelas).

Ketujuh, melakukan akad atas sesuatu yang ma'dum (tidak nyata adanya). Menurut Ibrahim bin Fathi, gharar yang dapat mempengaruhi sahnya jual-beli adalah tidak adanya (ma'dum) obyek transaksi. Ma'dum adalah keberadaan obyek transaksi yang bersifat spekulatif, mungkin ada atau mungkin tidak ada, maka jual-beli seperti ini hukumnya tidak sah (Muqtadir, 2006).

Dan Kedelapan, tidak adanya hak melihat atas obyek transaksi. Syahatah dan Adh-Dhahir menjelaskan bahwa tidak adanya hak melihat atas objek yang diperdagangkan adalah kondisi dimana obyeknya tidak dapat dilihat oleh salah satu dari pihak penjual atau pembeli pada saat transaksi berlangsung, baik dikarenakan komoditinya tidak ada atau ada tetapi berada dalam pembungkus. Jual-beli seperti ini juga sering disebut dengan jual-beli 'ainul ghaib, yaitu komoditi dikuasai secara penuh oleh penjual tetapi tidak dapat dilihat oleh pembeli (Syahatah \& Adh-Dhahir, 2005).

Selain ke delapan hal tersebut, endorser haruslah bersikap jujur dalam melakukan endorsement produk di media sosial instagram. Sikap jujur merupakan hal yang harus ada dalam setiap diri seorang Muslim (Syahputra, Etika Berbisnis Dalam Pandangan Islam, 2019). Jujur merupakan prinsip esensial dalam bermuamalah dan syarat fundamental dalam kegiatan bisnis (Syahputra, Etika Bisnis Dalam Islam: Suatu Jalan Keseimbangan Dalam Berbisnis, 2018). Apalagi hal ini menyangkut informasi yang diberikan kepada orang lain, diperlukan kebenaran informasi yang disampaikan, karena jika tidak akan merugikan pihak lain dan menimbulkan dampak yang lain pula. Apabila endorser menyampaikan informasi yang tidak sesuai dengan kenyataannya, maka sudah terdapat gharar dalam kegiatan tersebut.

Menggunakan media sosial penting memiliki akhlakul karimah, baik dari sisi endorser maupun pengguna. Konsep akhlaqul karimah tidak mengenal konsep regional, konsep ini bertumpu pada wahyu, 
meskipun akal berkontribusi dalam menentukannya (Aksin, 2016).

\section{KESIMPULAN}

Islam tidak membatasi inovasi dan kreatifitas dalam bermuamalah, namun ada ketegasan dalam batasan-batasan yang tidak boleh dilakukan. Meskipun saat ini penjualan produk menggunakan berbagai macam media, termasuk media sosial instagram, pihak yang melakukan endorsement tidak boleh mengesampingkan etika guna mendapatkan penghasilan. Endorser dalam menawarkan produk harus memberikan informasi yang benar dan tidak ada unsur penipuan, karena akan menjadi gharar jika hal tersebut dilakukan. Islam mengajarkan dalam bermuamalah tidak hanya berorientasi pada uang, namun juga keberkahan. Hal ini dapat dicapai bila antara pihak yang satu dan pihak yang lain menunjukkan kebaikan diantara mereka (HR. Bukhari).

Adapun dalam menyampaikan informasi, Islam mengaturnya sebagai berikut: 1) Menyampaikan informasi yang benar, tidak merekayasa serta memanipulasi fakta (QS. al-Hajj: 30), 2) Menyampaikan informasi dengan bahasa yang mudah dicerna, dipahami dan diterima masyarakat (QS. An-Nahl: 125), 3) Menerapkan kejujuran dan syariat Islam. Bagi calon konsumen diharapkan untuk meneliti fakta dan kebenaran terhadap informasi yang disampaikan endorser, guna menghindari kerugian (QS. al-Hujarat: 6) dan menyaring setiap informasi yang diterima.

Penelitian ini diharapkan menjadi rujukan bagi pihak produsen, endorser, dan calon konsumen dalam bermuamalah di media sosial. Disarankan bagi peneliti selanjutnya untuk meneliti lebih komprehensif dan menggabungkan penelitian dengan metode kuantitatif menggunakan model survey atau angket, sehingga hasilnya dapat lebih sempurna.

\section{DAFTAR PUSTAKA}

Aksamawanti. (2019). Gharar: Hakikat Dan Pengaruhnya Terhadap Akad. Syariati, 5(1), 43-56.

Aksin, N. (2016, Desember). Pandangan Islam Terhadap Pemanfaatan Media Sosial. Jurnal Informatika UPGRIS, 2(2), 119-120.

Al-Ghazali. (2005). Ihya 'Ulum al-Din. Beirut: Dar ibn Hazm.

Al-Qardhawi, Y. (2014). 7 Kaidah Utama Fikih Muamalah, Terj. Fedrian Hasmand. Jakarta: Pustaka AlKautsar. Jakarta: Pustaka Al-Kautsar. Al-Qusyairi, M. b.-H. (t.t.). Shahîh Muslim. Bayrût: Dâr Ihyâ al-Turâts al-'Arabî.

Al-Saati, A. R. (2003). The Permisible Gharar (Risk) in Classical Islamic Jurisprudence. J.KAU Islamic Economics, 16(2), 5.

Al-Saati, A.-R. (2003). The Permissible Gharar (Risk) in Classical Islamic Jurisprudence. Journal of King Abdulaziz University: Islamic Economics, 16(2), 3-19.

Al-Zuhayli, W. (2004). al-Fiqh al-Islami wa Adillatuh (Vol. 5). Damaskus: Dar alFikr.

Bishop, M. (2004). Essential Economics. London: The Economist and Profile Books Ltd.

Black, J. (1997). A Dictionary of Economics. UK: Oxford University Press.

Hamid, A. (2016). Praktek Jual Beli Sistem Online Ditinjau Dari Hukum Islam, Stadi Kasus Mahasiswa Universitas Al Asyariah Mandar, Kabupaten Polewali Mandar. J-ALIF: Jurnal Penelitian Hukum Ekonomi Syariah dan Sosial Budaya Islam, 1(1), 74-86.

Haroun, N. (2000). Fiqh Muamalah. Jakarta: Gaya Media Pratama.

Hosen, N. (2009). Analisis Bentuk Gharar dalam Transaksi Ekonomi. AlIqtishad, 1(1), 53-54.

Junaedi, D. (2016, September 14). Saintek Mutakhir. Retrieved Juli 09, 2020, from dedijunaedi.com: http://www.dedijunaedi.com/2016/0 9/gharar-dalam-bisnis- 
mlm.html\#: :text=Gharar\%20dari\% 20segi\%20fiqih\%20berarti,dapat\%2 0diserahkan\%2C\%20juga\%20terkan dung\%20ketidakrelaan.\&text=Denga n\%20demikian\%2C\%20dapat\%20di ambil\%20pengertian,penipuan $\% 2 \mathrm{C}$ $\% 20$ pertaruhan $\% 2 \mathrm{C} \%$

Kaplan, A., \& Haenlein, M. (2010). Users Of The World, Unite! The Challenges And Opportunities Of Social Media. Business Horizons, 53(1), 59-68.

Lidinillah, A. H., \& Mawardi, I. (2015, Pebruari). Praktik Gharar pada Hubungan Bisnis UMKM-Eksportir Furnitur di Jepara. JESTT, 2(2), 127.

Manzur, I. (1993). Lisan al-'Arab (Vol. 5). Beirut: Dar Sadr.

Mardani. (2012). Fiqih Ekonomi Syariah. Jakarta: PRENAMEDIA.

Morissan, A. M. (2010). Periklanan Komunikasi Pemasaran Terpadu. Jakarta: Penerbit Kencana.

Mowla, M. M. (2019). Identifying the Presence of Gharar in Buying and Selling Mechanism Under Different Kinds of the Market Structure. Global Journal of HUMAN-SOCIAL SCIENCE: ECONOMICS, 19(1), 3742.

Munawwir, A. W. (1997). al-Munawwir. Surabaya: Pustaka Progressif.

Muqtadir, I. b. (2006). Uang Haram. (A. K. dkk, Trans.) Jakarta: Amzah.

Muttaqin, A. (2010). Transaksi E-Commerce Dalam Tinjauan Hukum Jual Beli Islam. ULUMUDDIN, 6(4), 459-467.

Muttaqin, A. (2010). Transaksi E-Commerce Dalam Tinjauan Hukum Jual Beli Islam . Ulumuddin, 6(4), 466.

Nur, E. R. (2015, Juni). Riba dan Gharar: Suatu Tinjauan Hukum Dan Etika Dalam Transaksi Bisnis Modern. $A L$ 'ADALAH, 12(3), 647-662.

Pertiwi, W. K. (2019, 12). Sebanyak Inikah Jumlah Pengguna Instagram di Indonesia? Retrieved 07 10, 2020, from Kompas.com: https://tekno.kompas.com/read/2019/ 12/23/14020057/sebanyak-inikahjumlah-pengguna-instagram-di- indonesia\#: :text=Saat $\% 20$ itu $\% 2 \mathrm{C} \%$ 20total\%20pengguna\%20aktif,diban ding\%20rata\%2Drata\%20pengguna $\% 20$ global.

Powers, T., Advincula, D., \& Austin M, G. S. (2012). Digital and Social Media in The Purchase Decision Process. Journal of Advertising Research.

Rahman, M. F. (2018). Hakekat dan BatasanBatasan Gharar Dalam Transaksi Maliyah. SALAM; Jurnal Sosial \& Budaya Syar-i, 5(3), 256.

Redaksi. (n.d.). IBEC FEBUI. Retrieved 07 08, 2020, from https://www.ibecfebui.com/: https://www.ibecfebui.com/endorsement-dalamkacamata-ekonomi-islam/

Rusyd, I. (1981). Bidayah al-Mujtahid wa Nihayah al-Muqtasid (Vol. II). Beirut: Dar al-Ma'rifah.

Sabiq, S. (1994). Fiqih Sunnah (Vol. III). Kairo: Dar al-Fath li A'lam al'Arabiy.

Saiti, B., \& Abdullah, A. (2016). Prohibited Elements In Islamic Financial Transactions: A Comprehensive Review. Al-Shajarah, 21(3), 158.

Syahatah, H., \& Adh-Dhahir, S. M.-A. (2005). Transaksi dan Etika Bisnis Islam. (S. B. Satryo, \& Fauziah, Trans.) Jakarta: Visi Insani Publishing.

Syahputra, A. (2018). Etika Bisnis Dalam Islam: Suatu Jalan Keseimbangan Dalam Berbisnis. At-Tanmiyah: Jurnal Ekonomi dan Bisnis Islam, 1(2), 70 .

Syahputra, A. (2019). Etika Berbisnis Dalam Pandangan Islam. At-Tijarah: Jurnal Penelitian Keuangan dan Perbankan Syariah, 1(1), 21-34.

Taimiyah, I. (2002). Majmu' al-Fatawa (Vol. III). Beirut: Dar al-Fikr.

Taufiq. (2018). Memakan Harta Secara Batil (Perspektif Surat An-Nisa: 29 dan AtTaubah: 34). Jurnal Ilmiah Syari'ah, 17(2), 257.

Uddin, M. A. (2015). Principles of Islamic Finance: Prohibition of Riba, Gharar and Maysir. INCEIF, Kuala Lumpur, 
Malaysia (pp. 1-8). Kuala Lumpur: Munich Personal RePEc Archive.

Untari, D., \& Fajariana, D. E. (2018, September 2018). Strategi Pemasaran Melalui Media Sosial Instagram (Studi Deskriptif Pada Akun @ Subur_Batik). Widya Cipta, 2(2), 277.

Utami, P. B. (2014). "Strategi Komunikasi Pemasaran Melalui Endorsement pada Online Shop di Indonesia". Tesis - Universitas Negeri Sultan Ageng Tirtayasa.

Warde, I. (2001). Islamic Finance In The Global Economy. Skotlandia: Edinburgh University. 